\title{
生体リズムを考慮した光環境評価 \\ STUDY ON EVALUATION OF LIGHT ENVIRONMENT CONSIDERING BIOLOGICAL RHYTHM
}

\author{
久保田 真由*，岩田利枝** \\ Mayu KUBOTA and Toshie IWATA
}

\begin{abstract}
Recent lines of research show that light is important not only to human vision but also to human circadian regulation. The photometric quantities based on the relative photopic luminous efficiency function are used to express lighting condition. However it has been shown that the spectra sensitivity curve for circadian regulation is different from the spectra sensitivity curve for the photopic visual system. In order to support lighting design considering circadian regulation, in this paper, a method to evaluate light based on melatonin suppression, one of circadian rhythms, was proposed.

A formula, using spectrum distribution of radiant flux and action spectrum of melatonin suppression shown in a previous study, was developed to calculate the effect of light on human circadian regulation. Also a simplified formula was proposed in which illuminance and color temperature were used. The applicability of the simplified formula to actual spaces was tested by measuring light from lamps, the sun, and computer display and light in houses.
\end{abstract}

Keywords : Melatonin suppression, Visual sensitivity, Illuminance, Color temperature メラトニン分泌抑制, 視感度, 照度, 色温度

\section{1 研究の背景·目的}

照明技術の発達は人間の夜間活動を容易にした。建築物内での生 活時間が長くなり、自然光に依存する率が高かった時代と較心゙、昼 夜の光の浴び方が平坦化していると考えられる。現代ではさらに、 情報・通信の発達などにより「24 時間都市」が生まれ、一般市民の 生活スタイルも夜型化の傾向にある1)。これらの環境は利便性、効率 性を上げた反面、生体リズムの不調が引き起こす一因となっている 2)。生体リズムとは人間のさまざまな生体機能が約 1 日を周期として 変動していることである ${ }^{3)}$ 。生体リズムには松果体から分泌される メラトニンの血中濃度や深部体温変化があるが、これらは光によっ て 24 時間周期 (概日リズム)に同調しており、光の影響は社会的因子 より大きいことが示されている4)。

現代の光環境は、視覚（見える、明るい）に基づいて計画されて おり、視覚以外の生理的影響を考慮することはほとんどない。よっ て通常は、人の目に感じる明るさ（視感度）で放射エネルギーを重 みづけした光束を基本とした測光量を用いている。しかし、生体リ ズムの同調因子として影響の大きい波長域と視感度の高い波長域と
は必ずしも一致していないので5)、従来の測光量の評価だけでは、生 体リズムを乱さない光環境を計画するには不十分と考えられる。 本研究では、視覚だけではなく生体リズムへの影響を考えた建築 光環境設計を支援することを目的として、生体リズムへの影響に基 づいた光環境の評価法の開発を試みる。本論文では生体リズムの一 つとしてメラトニン分泌に着目し、波長毎の分泌抑制に基づいた新 しい光の単位の提案を行い、日常生活中の光の生体リズム影響につ いて検討した。

\section{2 本研究の位置づけ}

\section{1 受光状態と睡眠に関する既往研究}

日中の高照度光環境下での生活は、痴呆高齢者の睡眠障害な どの改善に有効であるため、高齢者施設や医療福祉施設におい て、光療法として照度と色温度の時間制御が実際に利用されている 7)8)。

日中の受光パターンと睡眠との関係について、森田ら ${ }^{99}$ は、受光 パターンを昼夜別の積算照度によってグループ化し、グループ毎の
* 日比谷総合設備(侏) 修士 (工学)

** 東海大学第二工学部 教授·博士 (工学)
Hibiya Engineering, Ltd., M. Eng.

Prof., School of Engineering II, Tokai University, Dr. Eng. 
唾液中のメラトニン分泌を比較している。夜間の積算照度が多い受 光パターンで夜間メラトニン分泌の抑制傾向が見られた。筆者らも、 これまでに、受光状態と睡眠状態の関係について研究を行ってきた 100-13)。学生被験者に対して、1日の積算曝露照度が多く、昼夜の積算 曝露照度比が高い方が、睡眠効率が有意に高いことを示した ${ }^{13) 。 こ ~}$ れらの研究では、測定されたパラメータは照度および時間である。

野口らは、起床時と入眠時の受光状態を研究している。起床 30 分 前から段階的に照度を上げていくことで、深部体温の上昇を促すと 報告している ${ }^{14)}$ 。また、入眠前の覚醒水準の低下に関して、入眠前 の光環境の照度・色温度から検討を行い、寝室入室から入眠までの 条件が低照度・低色温度の場合に覚醒度の低下がスムーズであった ことが示唆されている15)。この研究では、入眠時について、照度だ けでなく色温度も検討しているが、波長分布については言及してい ない。

\section{2 光とメラトニン分泌抑制に関する研究}

メラトニンは夜間時に脳の松果体より分泌されるホルモン で、入眠を促進する作用がある。メラトニン分泌は生体リズ ムの1つであるが、受光により抑制されることが知られている ${ }^{14) 。 ま ~}$ た、このメラトニン分必は、睡眠状態に影響を及ぼすだけでなく、 夜間のメラトニン分泌抑制が多い人 (シフトワーカーなど) ほど乳癌 の発症率が高いという報告もされている ${ }^{15)}$

Brainard らの研究 ${ }^{5}$ は、メラトニン分泌の抑制は光によって引き 起こされるが、その光受容体は視覚が持つ光受容体 (錐状体、桿状 体）とは作用スペクトルが異なることを示した社1)。メラトニンが もっとも分泌される夜間(夜間 2:30～3:00) に単波長の光刺激を与え る実験により、波長別に光子密度とメラトニンの抑制率の関係を測 定した。波長毎に測定された光子密度とメラトニン分泌の抑制率の 関係を(1)式に示すようなロジステック曲線に当てはめている。

$$
y=\frac{A 1-A 2}{1+\left(x / x_{50}\right)^{p}}+A 2 \cdots(1)
$$

$y:$ 抑制率 $[\%]$

$x:$ 光子密度 $\times 10^{12}\left[\right.$ photons $\left./ \mathrm{cm}^{2} / \mathrm{s}\right]$

$x_{50}$ : 抑制率 $50 \%$ 時の光子密度 $\times 10^{12}$ [photons $\left./ \mathrm{cm}^{2} / \mathrm{s}\right]$

$A I:$ 抑制率の下限 $[\%]$

$A 2:$ 抑制率の上限 $[\%]$

$p:$ 抑制率の変化量 $[-]$

(1) 式において $A I=0$ を仮定し、実験した $440 \sim 600 \mathrm{~nm}$ までの 8 条 件の曲線について回帰し、得られた結果を平均して、A2=66.9、 $p=1.27$ を決定している。図 1 に実験によって示された光子密度とメ ラトニン分泌の抑制率の関係を示す。波長毎に光子密度とメラトニ ン分泌の抑制率が異なることが分かる。

Brainard らは、さらにメラトニンを $50 \%$ 抑制寸るときの光子密度 $x_{50}$ を波長每に求め、 $460 \mathrm{~nm}$ 時の光子数を 1 としたときの相対比を 算出し、この算出した相対比の逆数を波長の関数として示した。こ れは 1 光子あたりがもつ抑制効果を $460 \mathrm{~nm}$ の光子何個分にあたるか を示していることになるが、論文中では「メラトニン分泌抑制の作 用スペクトル曲線」と呼んでいる。さらに、これがビタミン $\mathrm{Al}$ ベー スのロドプシン相対分光曲線 ${ }^{15)}$ によく当てはまったので、メラトニ

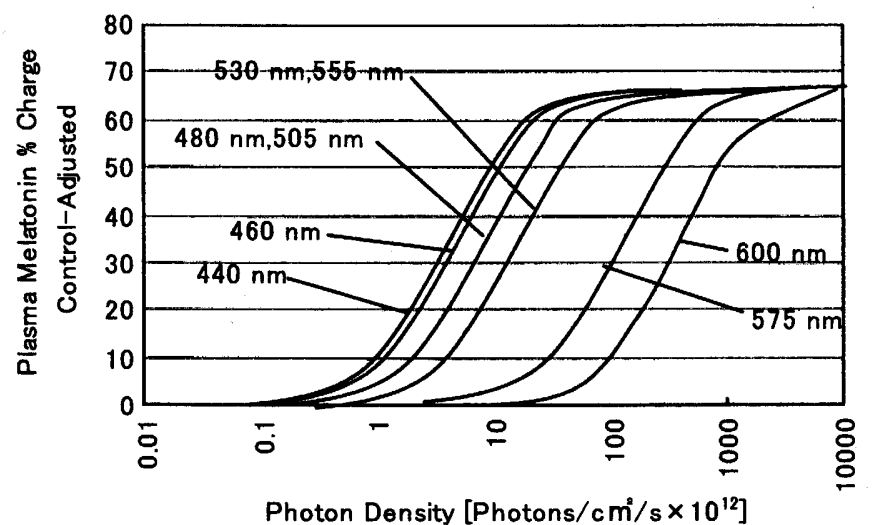

図 1 光子密度とメラトニン分泌の抑制率の関係 ${ }^{5)}$

ン分泌抑制の作用スペクトル曲線=ビタミン $\mathrm{A} 1$ ベースのロドプシン 相対分光曲線としている。

\section{3 本研究の特徴}

光のメラトニン抑制効果に関与するパラメータとして、(1)光の分光 分布、(2)単位時間当たりの光の照射量、(3)照射時間、(4)照射時刻があ げられる。Brainard らは(1)と(2)のみを検討し、(3)と(4)は一定としてい る。本論文でも(3)と(4)については後の研究課題として残し、(1)と(2)を 扱うことにした。

Brainard らの研究結果を見ると、生体リズムへの影響を考慮した光 環境評価には、測光量だけでは不十分な可能性が高い。本研究ではま す、分光分布の影響の大きさを示すため、日常生活中の光のメラトニ ン抑制影響に基づいた評価を試みた。これは照度等の測光量が視感度 で重み付けして明るさを示すことと同様に、メラトニン分泌の作用ス ペクトルで重み付けして生体リズム影響を示すものである。

Brainard らによって示された作用スペクトルは、夜間 2:30〜3:00 にかけて目に照射することによる 3:00のメラトニン抑制効果を基淮 にしている。(3)照射時間、(4)照射時刻が異なれば抑制効果が異なる可 能性もあるが、一定の条件下での波長毎の抑制効果の相対值を示寸指 標になる。この作用スペクトルを用いてメラトニン分泌への影響の大 きさで光環境を評価する方法を示した。さらに、照度と色温度を用い てメラトニン分泌抑制を示し、実空間での適用性を検討した。

\section{3 メラトニン分泌を考慮した光環境評価}

3.1 メラトニン分泌抑制の作用スペクトルの単位エネルギー換算 Brainard らの研究では、光了密度が用いられているが、比視感度と 比較するには、単位エネルギーに換算しなくてはならない。1 光子が 持つエネルギー $E q(\lambda)$ は、(2) 式によって求められる16)。

$E q(\lambda)=h \cdot c / \lambda \quad \cdots(2)$

$E q(\lambda): 1$ 光子が持つエネルギー $[\mathrm{W} \cdot \mathrm{s} /$ photon $]$

$h:$ プランク定数 $\left[\mathrm{W} \cdot \mathrm{s}^{2}\right]\left(=6.257 \times 10^{-34}\right)$

$c:$ 光子速度 $[\mathrm{m} / \mathrm{s}]\left(=3 \times 10^{8}\right)$

$\lambda:$ 波長 $[\mathrm{m}]$

各波長の単位エネルギーあたりの光子密度を同じ抑制効果のある $460 \mathrm{~nm}$ の光子数を $q_{460}(\lambda)$ として示す。これは (3) 式のように波長毎 のメラトニン分泌抑制率の相対比 $S_{s}(\lambda)$ (Brainard の「メラトニン分泌 
抑制の作用スペクトル曲線」)と 1 光子が持つエネルギー $E q(\lambda)$ に よって求められる。

$$
q_{460}(\lambda)=S_{s}(\lambda) / E q(\lambda) \cdots(3)
$$

$q_{460}(\lambda):$ 単波長 $(\lambda)$ の光の単位エネルギーあたりの $460 \mathrm{~nm}$ 相当光子数 [photons $/ \mathrm{W} / \mathrm{s}$ ]

$S_{S}(\lambda):$ メトニン分泌の相対比 ${ }^{14)}[-]$

これを比視感度と同様、最大 $1(\lambda=460 \mathrm{~nm})$ の比の形として示寸 ため、(4) 式のように計算し、メラトニン分泌抑制の感度比(以下メ ラトニン感度比と記す) を求めた。

$$
V_{M}(\lambda)=q_{460}(\lambda) / q_{460}(460) \quad \cdots(4)
$$

$V_{M}(\lambda):$ メトニン感度比 [-]

$q_{460}(460): 460 \mathrm{~nm}$ の単位エネルギーあたりの光子数

$$
\text { [photons } / \mathrm{W} / \mathrm{s}]\left(=2.3 \times 10^{18}\right)
$$

図 2 に視感度 $V(\lambda)$ と (4) 式のように求めたメラトニン分泌の抑制 感度 $V_{M}(\lambda)$ を比較したものを示す。これよりメラトニン分泌の抑 制感度と比視感度の作用スペクトルが異なることが明らかである。

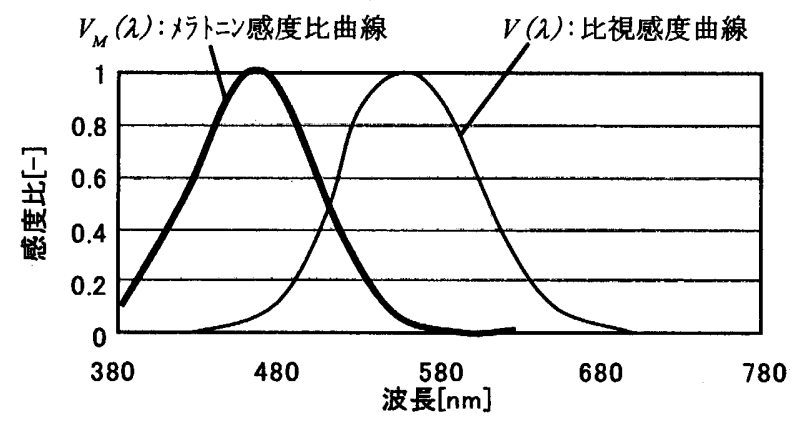

図 2 視感度とメラトニン感度

\section{2 複数の波長から構成される光の換算}

上記のように Brainard らの作用曲線に基づいて各波長の光の光子 密度を最大感度波長 $(\lambda=460 \mathrm{~nm})$ に相当する光子密度に換算するこ とができる。しかし、通常、光源からの光や空間で反射された光は、 複数の波長から構成されている。そこで、メラトニン感度比を用い て、全ての波長を $460 \mathrm{~nm}$ 相当光子密度 $q_{460}$ に換算し、それを積算し て $460 \mathrm{~nm}$ 相当光子密度 $q_{460}$ を求める。これは、光束の算出と同じ考 え方である(注2)。

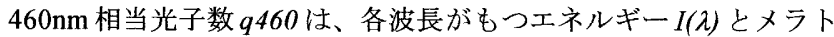
ニン感度 $V_{M}(\lambda)$ から次のように表される((5)式)。

$$
q_{460}=q_{460}(460) \int \bar{I}(\lambda) \cdot V_{M}(\lambda) d \lambda \quad \cdots(5)
$$

$q_{460}$ : 複数の波長から構成される光の $460 \mathrm{~nm}$ 相当光子密度 [photons $/ \mathrm{cm}^{2} / \mathrm{s}$ ]

$\bar{I}(\lambda)$ : 単位面積あたりの分光エネルギー $\left[\mathrm{W} / \mathrm{cm}^{2} / \mathrm{nm}\right]$

$V_{M}(\lambda)$ :メラトニン感度比 $[-]$

これにより分光分布が異なる波長域のある光を「メラトニン抑制 影響」の相対的大きさで示寸ことができた。されに具体的な影響の 大きさを表すため、 $460 \mathrm{~nm}$ の光子密度 - 抑制率曲線を使って抑制率 (Melatonin Suppression として以下 $M S$ と表す) $M S$ を求めることにし た。MS はその光を夜間 2:30〜3:00 に照射したときの 3:00のメラト ニンの抑制率と定義される。 $M S$ の算出式を(6) 式に示す。

$$
M S=\frac{0-66.9}{1+\left(q_{460} / x_{50}(460)\right)^{1.27}}+66.9 \cdots(6)
$$

$M S:$ メトニン分泌の抑制率 $[\%]$

$x_{50}(460): 460 \mathrm{~nm}$ 時の抑制率 $50 \%$ の光子密度 $\times 10^{12} \quad$ [photons $/ \mathrm{cm}^{2} / \mathrm{s}$ ] $(=4.96)$

\section{3 色温度·照度と $460 \mathrm{~nm}$ 相当光子密度と $M S$}

光源などから光子密度を算出する場合、分光分布を測定しなくて はならないが、一般的に分光分布の測定は計測器の大きさ、データ 数の多さから考えて扱いが簡単ではない。そこで、一般に容易に現 場測定ができる照度・色温度から $460 \mathrm{~nm}$ 相当光子数 $q 460$ を算出する ため、黒体の放射温度と $q_{460}$ 及び $M S$ の変動について検討すること にした。

黒体放射発散度 Me は、(7)式によって求められる ${ }^{17)}$

$$
\begin{aligned}
& M e(\lambda, T)=\frac{c_{1}}{\lambda^{5}} \cdot \frac{1}{\exp \left(c_{2} / \lambda T\right)^{-1}} \cdots(7) \\
& M e: \text { 黒体放射発散度 } \quad\left[\mathrm{W} / \mathrm{m}^{2}\right] \\
& T: \text { 絶対温度 } \quad[\mathrm{K}] \\
& c_{1}: \text { プランクの第一定数 } \quad\left[\mathrm{W} / \mathrm{m}^{2}\right]\left(=3.74150 \times 10^{-16}\right) \\
& c_{2}: \text { プランクの第二定数 } \quad\left[\mathrm{W} / \mathrm{m}^{2}\right]\left(=1.4388 \times 10^{-2}\right)
\end{aligned}
$$

図 3 に絶対温度別の黒体放射の相対分光分布を示す。図 3 では、波 長 $580 \mathrm{~nm}$ でのエネルギーを一致させた。分光分布を基に黒体 $2000 \mathrm{~K}$ 〜 10000Kについて、1000K ごとに $460 \mathrm{~nm}$ 相当光子密度を算出した。

図 4 に色温度と単位照度あたりの $460 \mathrm{~nm}$ 相当光子密度(以下

と $q_{460} / E$ と示す)の関係を示す。 $q_{460} / E$ は、 $460 \mathrm{~nm}$ 相当光子 数に照度を除して算出した。色温度が高いほど、単位照度あた りの $460 \mathrm{~nm}$ 相当光子密度が多い。

$2000 \mathrm{~K} \sim 10000 \mathrm{~K}$ の相関色温度 $C C T$ と $q_{460} / E$ の回帰式を(8) 式 (以下 $q_{460} / E$ 式と記す) に示寸。

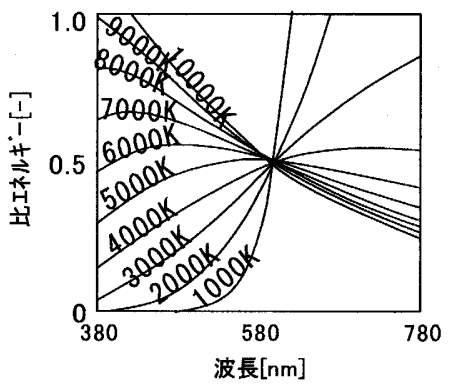

図 3 絶対温度別の黒体放射体の 相対分光分布

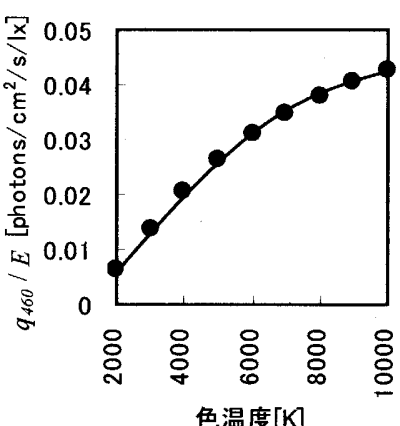

図 4 単位照度あたりの $460 \mathrm{~nm}$ 相当光子数 
この $q_{460} / E$ 式から $q_{460}$ が求められ、これを(6) 式に代入するこ とで、MS を算出することができる。

$q_{460} / E=1.6 \times 10^{-14} \cdot C C T^{3}-7.0 \times 10^{-10} \cdot C C T^{2}$

$$
+1.1 \times 10^{-5} \cdot C C T-0.0133 \cdots(8)\left(q_{460} / E \text { 式 }\right)
$$

$(2000 \mathrm{~K} \leqq C C T \leqq 10000 \mathrm{~K})$

$E$ : 照度 $[\mathbf{l} \mathbf{x}]$

$C C T:$ 相関色温度 $[\mathrm{K}]$

\section{4 異なる光源に対する提案式の適用性検討}

黒体の色温度を用いた $q_{460} / E$ 式の実際の光源への適用性を検討 するため、生活中の光源を測定し、 $q_{460} / E$ 式の誤差を比較した。

\section{1 実測方法}

日常生活中で光源として使用されている人工光源と自然光 (昼光) の測定を行った。実測には、分光放射計 (LP200:Light-Spex 社製) と 照度計（T-10:KONICAMINOLTA 社製）を用いた。

昼光の測定に関しては、2003 年 12 月 (快晴)に東海大学代々木校 舎の屋上にて、水平面の分光分布、照度を 1 時間ごとに測定した。

人工光源の測定に関しては、蛍光ランプ (昼光色、昼白色、電球色) と白熱電球を内表面が黒いマットな素材でできた測定 BOX（図 5) 内に取り付けて簡易な測定を 行った。

\section{2 実測結果}

\section{2.1 昼光}

図 6 に蜸光の分光分布の時刻変 動を示す。13 時に関しては、一時 的に曇ったため、他の時間と異 なる分光分布を示した。

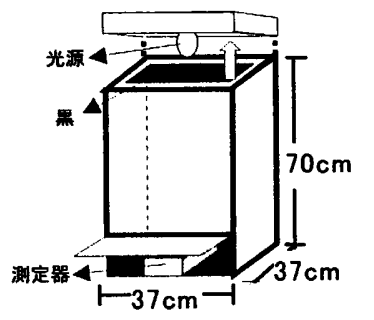

図 5 光源の测定 BOX
図 7 に照度と分光分布から求めた $M S$ を示す。日中は、 $M S$ が高く、 16 時から急激に抑制率が減少した。

\section{2.2 人工光源}

図 8 に人工光源の分光分布を示寸。図 9 に照度と分光分布から求 めた $M S$ を示す。等しい照度下においても、光原色によって $M S$ が異 なる。特に、電球色蛍光ランプと白熱電球は、昼光色蛍光ランプ、昼 白色蛍光ランプより、抑制率が低いことが示された。

\section{2. $3 q_{460} / E$ 式の誤差}

黒体放射と比較するため、 $q_{460} / E$ を算出した。図 $10 に q_{460} / E$ 式より求められる $q_{460} / E$ と(5) 式を用いて分光分布から計算した $q_{460} / E$ を示す。

熱放射である昼光と白熱電球は、黒体放射から求められた計 算值とほぼ一致した值を示した。ルミネセンス放射の蛍光ラン プは、ランプによって分光分布が異なるため、熱放射に比べて $q_{460} / E$ 式の誤差が認められたが、色温度が高いと $q_{460} / E$ が大 きくなるという傾向は一致した。

黒体の軌跡からの色度差 $\Delta \mathbf{u v}$ と $q_{460} / E$ 式の誤差の比較を 行った。 $q_{460} / E$ 式の誤差は、(9) 式に示す。

$$
\Delta q_{460} / E=\frac{\left(q_{460} / E\right) \text { 分 }-\left(q_{460} / E\right) \text { 色 }}{\left(q_{460} / E\right) \text { 分 }} \cdots(9)
$$

$\left(q_{460} / E\right)$ 分: 分光分布から求めた $q_{460} / E$

$\left(q_{460} / E\right)$ 色: 色温度から $q_{460} / E$ 式を用いて算出した $q_{460} / E$

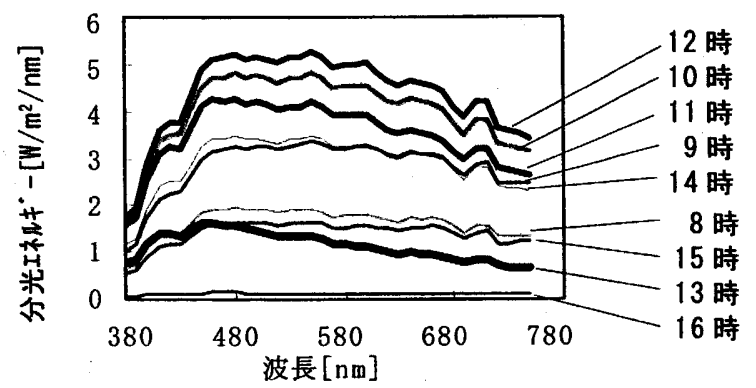

図 6 昼光の分光分布

照度 一一分光分布から求めた $M S$

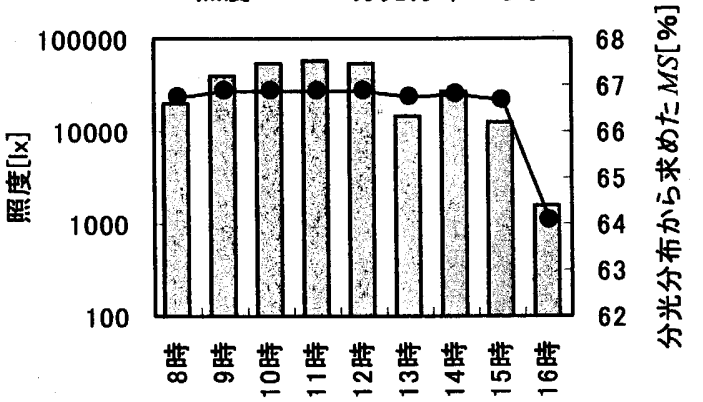

図 7 昼光の照度と分光分布から求めた $M S$ の時刻変動

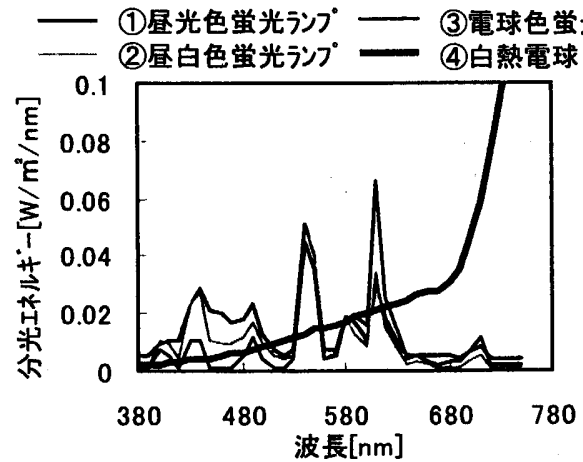

図 8 人工光源の分光分布

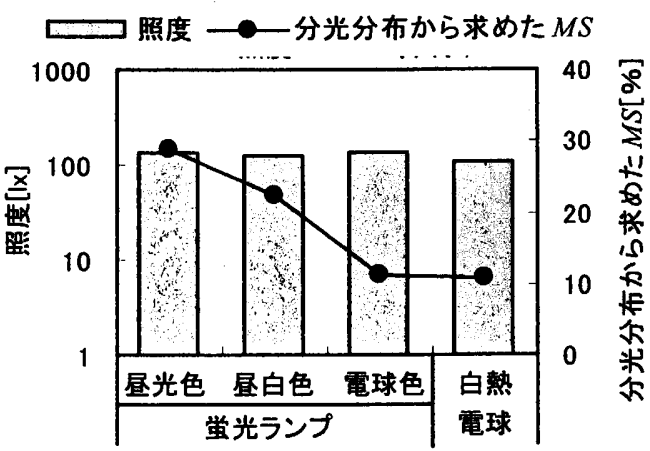

図 9 人工光源の照度と分光分布から求めた $M S$

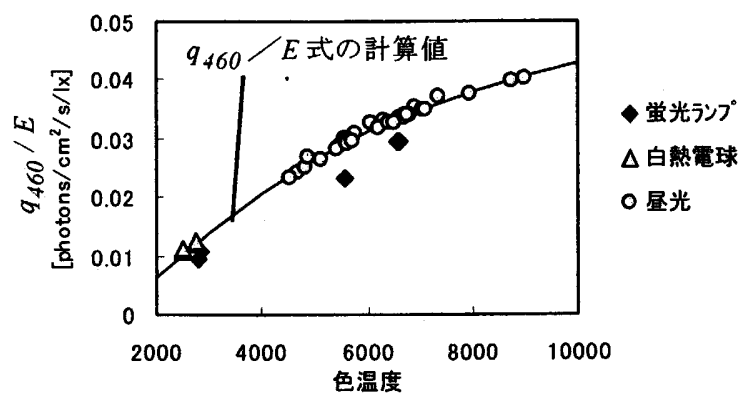

図 10 黒体放射と光源の $q_{460} / E$ 
図 11 に黒体の軌跡からの色度差 $\Delta \mathrm{uv}$ と、 $q_{460} / E$ 式からの計算值 と分光分布からの計算値の差 $\Delta\left(q_{460} / E\right)$ を示す。

白熱電球、昼光は色度差によらず計算値差は $-3 \sim 10 \%$ であっ たが、蛍光ランプでは $-10 \sim-20 \%$ の計算値差を示し、 $q_{460} / E$ 式による值の方が大きくなった。

\section{5 実空間における提案式の適用性検討}

実際の生活空間は分光分布の異なる複数光源で構成され、さらに 内装などの反射成分の影響が大きい。そこで $q_{460} / E$ 式の日常生活 中への適用性の確認を行った。

ここでは、近年パソコン画面を見る機会も多くなっているこ とから、パソコン画面を見た場合に目に入る光と、住宅の各空 間で目に入る光を実測し、 $q_{460} / E$ 式の誤差を検討した。

\section{1 パソコン画面の測定}

背景画面の色は、黒(パソコンの電源を入れていない状態)、白、 赤、黄、緑、青の 6 色とし、パソコン作業中に目に入ってくる 光としてパソコン画面の正面中央前 $30 \mathrm{~cm}$ 鉛直面で測定した（図 12)。通 常のパソコン使用時を想定して室内 照明（昼白色営光灯 $4200 \mathrm{~K}$ ) を点灯し た。画面は 15 型 TFT 液晶ディスプレ イ (EPSON 社製)、各色の RGB 設定 は、白 ( R $255, \mathrm{G} 255, \mathrm{~B} 255$ )、赤

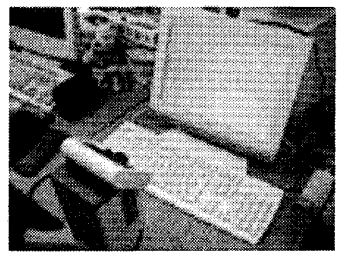

図 12 測定風景
$(\mathrm{R} 255, \mathrm{G} 0, \mathrm{~B} 0) 、$ 黄 $(\mathrm{R} 255, \mathrm{G} 255, \mathrm{~B} 0) 、$ 緑 $(\mathrm{R} 0, \mathrm{G} 255, \mathrm{~B} 0)$ 、青 $(\mathrm{R} 0, \mathrm{G} 0, \mathrm{~B} 255)$ とした。

図 13 に色温度と $q_{460} / E$ を背景画面の色別に示す。短波長側 のエネルギーが大きい青画面時が抑制率が最も高く、 $q_{460} / E$ 式の計算值と近い值を示した。図 14 に黒体の軌跡からの色度 差 $\Delta \mathrm{uv}$ と、 $q_{460} / E$ 式からの計算値と分光分布からの計算値の 差 $\Delta\left(q_{460} / E\right)$ を示す。色度差が大きいほど、計算値差が大き い傾向にあり、-20〜0\% 差となった。

\section{2 住宅における測定}

住宅では目の位置、視点の移動を考慮し、代表点として室内 中央、高さ $1 \mathrm{~m}$ での水平面において、分光分布と照度・色温度の 測定を行った。室内の一定の照明空間の測定を行うため、測定 は日没後 (昼光の影響なし) に行った。

図 15 に色温度と $q_{460} / E$ を示す。住宅においても $q_{460} / E$ 式の 計算值と近い值を示した。図 16 に黒体の軌跡からの色度差 $\Delta \mathrm{uv}$ と、 $q_{460} / E$ 式からの計算値と分光分布からの計算値の差 $\Delta\left(q_{460} / E\right)$ を示す。浴室では $-30 〜 30 \%$ の計算值差が見られたが、居間、寝室、 台所では計算值差が $-27 \sim 2 \%$ で、計算值差の 90 パーセントタイル 值が - 16\%であった。浴室で計算值差が正となるのは色温度の 低い場合であった（図 15 参照）。概ね予測のずれが安全側であ り、 $q_{460} / E$ 式は実空間に適用可能であると考えられる。

\section{3 等 $M S$ チャートによる検討}

$M S$ と照度・色温度との関係を見るため、図 17 に照度一色温度 図に等 $M S$ 曲線をひいたものを示す。

例えば、 $M S$ を $10 \%$ にしたとき、昼光色営光ランプ $(6700 \mathrm{~K})$ （図 17 中口）を使用した空間では、照度を37.3[1x] となるが、 電球色蛍光ランプ $(3000 \mathrm{~K}$ ) (図 17 中 $\diamond$ ) に変えると、照度が

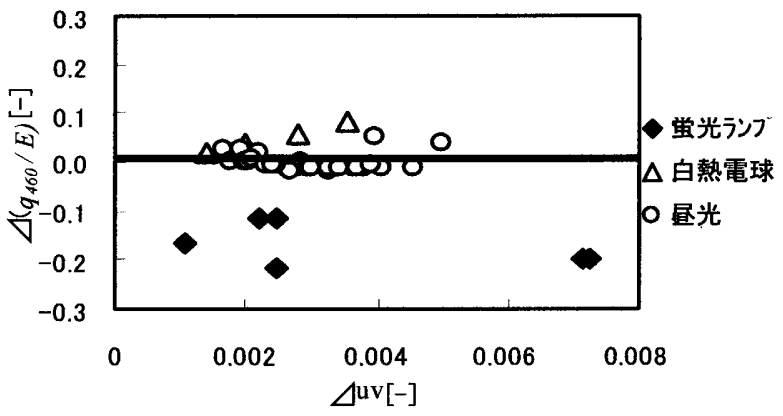

図 11 色度差 $\Delta \mathrm{uv}$ と計算値差 $\Delta\left(q_{460} / E\right)$ （光源別）

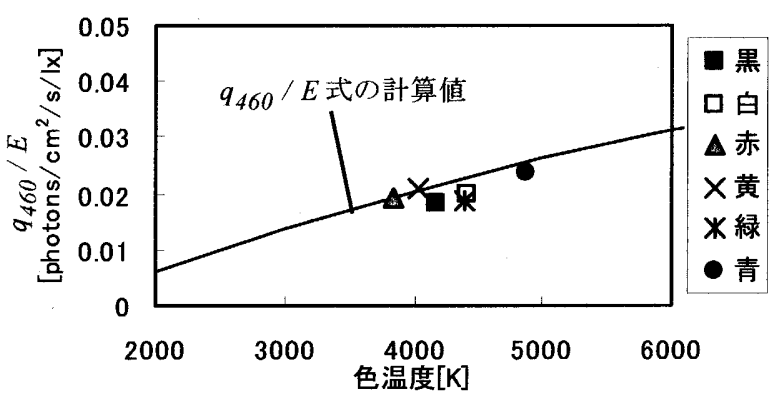

図 13 色温度と $q_{460} / E$ (パソコン画面)

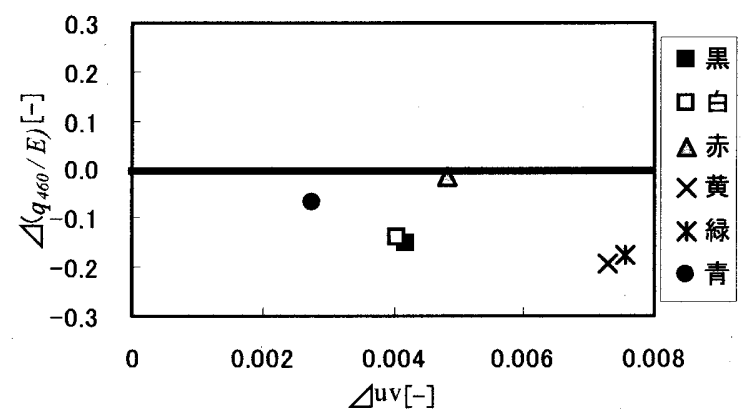

図 14 色度差 $\Delta \mathrm{uv}$ と $\Delta\left(q_{460} / E\right)$ (パソコン画面)

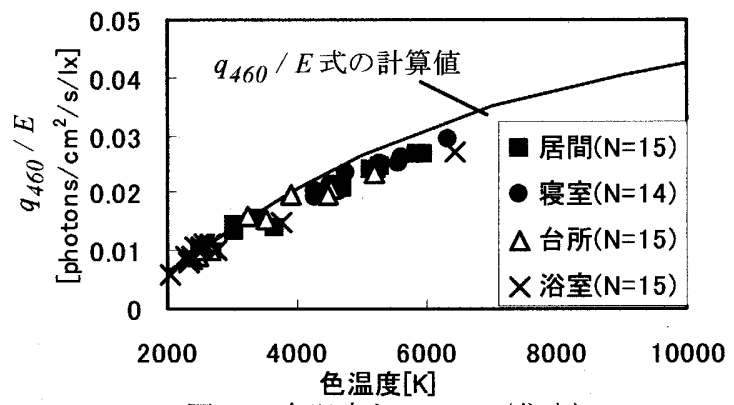

図 15 色温度と $q_{460} / E$ (住宅)

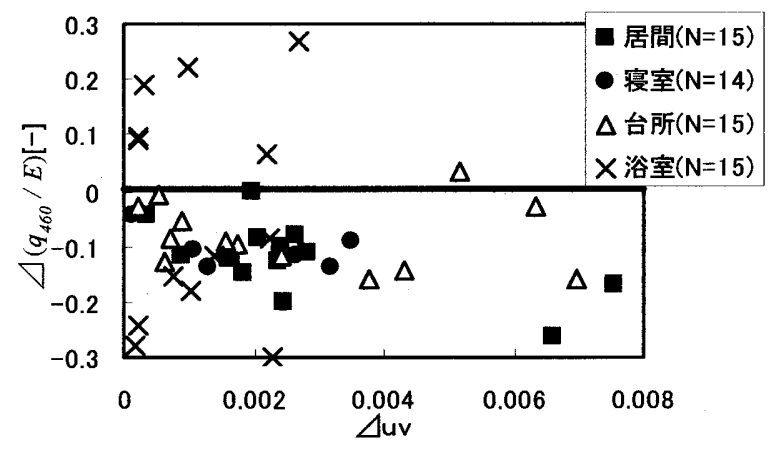

図 16 色度差 $\Delta \mathrm{uv}$ と $\Delta\left(q_{460} / E\right)$ (住宅) 


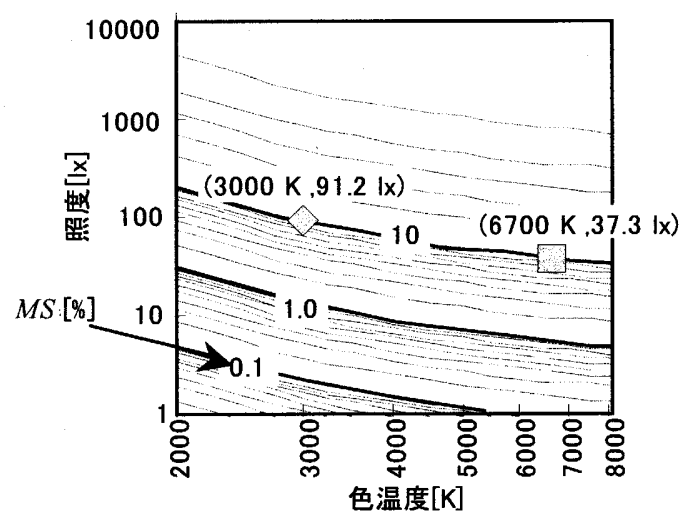

図 $17 q_{460} / E$ 式から求めた $M S$ と色温度·照度

$91.2[1 \mathrm{x}]$ となる。

6. まとめ

本研究では、光の生体リズムへの影響を評価するため、視感 度に基づいた測光量ではなく、メラトニン分泌を考慮した評価 法の提案を試みた。結果を以下にまとめる。

(1) メラトニン分泌抑制の作用スペクトル曲線を基に、光の分光分 布から $460 \mathrm{~nm}$ 相当光子密度 $q_{460}$ 、および $M S$ （夜間 $2: 30 \sim 3: 00$ に照 射したときの 3:00のメラトニン分泌抑制率）への換算式を作成した。

(2) 色温度・照度による $q_{460}$ および $M S$ の簡易式を提案した。

(3) 簡易式の適用性を光源 (昼光・白熱電球・蛍光ランプ)、異なる背 景画面色を用いたパソコン画面前、住宅内の各空間について行い、 概ね適用できることを示した。

(4) 色温度、照度から $M S$ を知る図を示した。

本研究で求めた $q_{460}$ は放射束をメラトニン抑制感度で重みづけし たもので「照度」に相当する。また、 $M S$ は $q_{460}$ の数值の意味を具 体的に示すためのもので、一定の条件下での「読みやすさ」あるい は「明るさ感」に相当する。ここでは $M S$ は Brainard らの研究に基づ き、夜間 2:30〜3:00に照射した場合の 3:00 メラトニン分必の抑制率 である。「2.3 本研究の特徵」に述べたように「照射時間」と「照 射時刻」は一定としており、異なる時刻、異なる照射時間のメラト ニン分泌の抑制効果については今後の検討が必要である。また、こ こではBrainard らの研究結果 ${ }^{5}$ に基づいているが、注 1)に示したよ うに現時点では作用スペクトルに関しても研究者によって若干異な ることを付記しておく。

\section{謝辞}

本研究は、平成 14 年度財団法人 旭硝子財団( 第 3 分野 特定 研究助成 B）「人間の生体リズムに基づいた照明設計法に関する 研究」の助成を得た。また、実測は、当時東海大学工学部建築学科卒 論生の近藤可奈子氏によるところが大きい。記して謝意を表します。

注1）Brainardらはの実験では瞳孔㹡張郕を用いて瞳孔径の収維が起こらない状態 で顔を積分球で覆って光に曝露している。Brainard は cone,rod以外の光受容体が 網膜上あるいはその付近にあると考えている。一方Bersonらは網膜の外側にある ganglion cellがそのレセプターであると報告している*。彼らの報告ではピークは 479nm と Brainard よりやや長波長となっている。

*M.D. Rollag, D.M. Berson and I. Provencio:Melanopsin, ganglion cell photoreceptors, and mammalian entrainment, J. Biol. Rhythms, 18(3), pp.227-234, 2003

注 2) Brainardらは「光子密度」を用いているので撮密（単位的）には「照度」と 同じになる。光束とするためには瞳孔面積を乗じる必要があるが、実験時の瞳孔面 積はほぼ一定であるのでここでは(5)式が光束と同じ考え方であると表記した。

\section{本論文に関連した口頭発表}

久保田真由、岩田利枝、近藤可奈子:生体リズムを考慮した光環境評価に関する研 究、日本建築学会学術講演梗概集、D-1、pp.925-926、2004

\section{参考文献}

1)NHK放送文化研究所、日本人の生活2000、NHK国民生活時間調查、日本放送協 会出版、2002

2)白川修一郎: 人間の睡眠一覚醒リズムと光(心地よい眠りと目覚め)、照明学会誌、 84(6)、pp.354-361、2000

3)例えば、亀井雄一、内山真、大川匡子: 睡眠相後退症候群、臨床精神医学、26(3)、 pp.315-322、1997

4)本間研一他：自然睡眠、臨床脳波 No.6, pp.9-15, 2002

5)G. C. Brainard, J. P. Hanifin, J. M. Greeson, B. Byrne, G. Glickman, E. Gerner, and M. D. Rollag: Action Spectrum for Melatonin Regulation in Humans: Evidence for a Novel Circadian Photoreceptor, The Journal of Neuroscience, 21(16), pp.6405-6412, 2001 6)Thapan,K., Arendt,J.and Skene, D.J., Action spectrum for melatonin suppression: Evidence for a novel non-rod, non-cone photoreceptor system in humans, Journal of Physiology, 535, pp.261-267, 2001

7)伊藤武夫、小山恵美:生体リズムを考應した最近の医療福祉施設の照明、照明学 会誌、84(6)、pp.362-367、2000

8)大川匡子:特別薑護老人ホームでの光療法事例、照明学会誌、84(6)、pp.368-371、 2000

9)Morita T., Koikawa R., Ono K., Terada Y., Hyun K., and Tokura H.Influence of the amount of light received during the day and night times on the circadian rhythm of melatonin secretion in women living diurnally, Biological Rhythm Research, 33(3), pp.271277,2002

10)宮尾慶太、岩田利枝:昼夜の曝露照度の差異に関する調查研究、日本建築学会学 術講演梗概集、D-1、pp.435-436、2000

11)田村弘、岩田利枝: 曝露照度と活動量に関する調查研究、日本建築学会学術講演 梗概集、D-1、pp.435-436、2001

12) 久保田真由、岩田利枝、長谷部徹：曝露照度が睡眠状態に与える影響に 関する実測調查、日本建築学会学術講演梗概集 D-1、pp.399-400、2002

13) T. Iwata , T. Hasebe and M. Kubota: Study on exposed illuminance in daily life and circadian rhythm, Proceeding of CIE 25th Session, Division3 Presented Paper, pp.6063,2003

14) 野口公喜、白川修一郎、駒田陽子、小山恵美、阪口敏彦: 天井照明を用 いた起床前漸增光照射による目覚めの改善、照明学会誌、85(5)、pp.315-322、 2001

15)Noguchi $H$. , and Sakaguchi T.:Effect of illuminance and color temperature on lowing of physiological activity, Applied Human Science, 18(4), pp.117-123, 1999 16)C.A.Bernecker, G.C.Brainard, F.J.Fernsler, M.D.Rollag, R.R.Long, S.Tierney, and J.R.Gaddy:Biological Effects of Architectural Lighting and Their Associated Energy Utilization, Journal of the illuminating Engineering Society, 1994

17)R.G. Stevens: Epidemiological evidence on artificial lighting patterns and risk of breast cancer, 5th International LRO Lighting Research Symposium, 2002 18)Partridge J.C., De Grip W.G.;Anew template for rhodopsin(vitamin Al based) visual pigments, Vision Research, 31, pp.619-630, 1991

19) 例えば、Herbert A. Pohl: 理学と工学のための量子力学入門、内田老鶴戋、 pp.6-22、1976

20) 例えば、照明ハンドブック (第 2 版)、社団法人照明学会、pp.8、2003 